\title{
Evaluasi Keunggulan Genetik Sapi Peranakan Ongole Betina Dengan Dua Metode Yang Berbeda Di Satker Sumberrejo-Kendal
}

\section{(Evaluation of Genetic Superiority of Female Ongole Breeds by Two Different Methods in the Sumberrejo-Kendal Work Unit)}

\author{
Arista Seftiana, Sutopo, Edy Kurnianto \\ Laboratorium Genetika, Pemuliaan dan Reproduksi Ternak \\ Fakultas Peternakan dan Pertanian Universitas Diponegoro, Semarang \\ Email : ariska.seftiana@gmail.com
}

Diterima : 4 April 2019/Disetujui : 25 Mei 2019

\begin{abstract}
ABSTRAK
Tujuan dari penelitian ini adalah untuk menentukan keunggulan sapi Ongole Grade (PO) di Satker-Sumberrejo, Kendal menggunakan dua metode yang berbeda, yaitu MPPA dan EBV. Bahan yang digunakan dalam penelitian ini adalah 48 ekor sapi.Metode yang digunakan dalam penelitian ini adalah observasi menggunakan rekaman untuk mendapatkan catatan silsilah sapi, kemudian digunakan dalam perhitungan.Korelasi Spearman digunakan untuk membandingkan dua metode seleksi yaitu MPPA dan EBV. Hasil penelitian ini menunjukkan rata-rata berat lahir adalah 29,35 $\pm 2,13 \mathrm{~kg}$ sedangkan berat sapih 112,58 $\pm 24,17 \mathrm{~kg}$. Berat badan standar untuk berat lahir adalah $30,91 \pm 1,97 \mathrm{~kg}$, sedangkan untuk berat menyapih adalah $110,10 \pm 11,20 \mathrm{~kg}$. Uji korelasi Spearman menunjukkan tidak ada perbedaan yang signifikan antara MPPA dan EBV.Dapat disimpulkan bahwa MPPA dan EBV dapat digunakan dalam pemilihan sapi.
\end{abstract}

Kata kunci: Silangan Ongole, nilai pemuliaan, EBV, MPPA

\begin{abstract}
The objective of this study was to determine the superiority of Ongole Grade (PO) cows in Satker-Sumberrejo, Kendal using two different methods, those were MPPA and EBV. Materials used in this study were 48 heads. Method applied in this study was observation using the recording to obtain a pedigree record of a cow, then used in the calculation. Spearman correlation was used to compare two methods of selection those were MPPA and EBV. The result of this study showed the mean birth weight was $29.35 \pm 2.13 \mathrm{~kg}$ while weaning weight was $112.58 \pm 24.17 \mathrm{~kg}$. Standardized body weight for birth weight was $30.91 \pm 1.97 \mathrm{~kg}$, while for weaning weight was $110.10 \pm 11.20 \mathrm{~kg}$. Spearman correlation test indicated no significant differences between MPPA and EBV. It can be concluded that MPPA and EBV can be used in the selection of cow.
\end{abstract}

Keywords: Ongole Cross, Breeding value, EBV, MPPA

\section{PENDAHULUAN}

Kebutuhan daging dari tahun ke tahun terus mengalami peningkatan seiring dengan bertambahnya jumlah penduduk, peningkatan pendapatan dan kesejahteraan masyarakat serta semakin meningkatnya kesadaran masyarakat akan pentingnya protein hewani. Namun penyediaan daging masih tergolong rendah apabila dibandingkan dengan permintaan. Oleh karena itu perlu adanya upaya untuk meningkatkan jumlah populasi sapi potong. Sapi potong merupakan sapi yang menghasilkan daging yang banyak dikonsumsi masyarakat untuk memenuhi 
kebutuhan protein hewani. Populasi sapi potong dapat ditingkatkan dengan cara pemilihan bibit unggul. Bibit unggul dapat diperoleh dari induk yang memiliki mutu genetik yang baik, yang diperoleh dari proses seleksi.

Pemilihan bibit sapi betina yang baik tidak dapat dilakukan hanya dengan melihat penampilan luarnya saja (eksterior). Seleksi yang akurat adalah berdasarkan nilai pemuliaan sapi betina tersebut. Seleksi dibedakan menjadi dua yaitu seleksi alam dan seleksi buatan (Kurnianto, 2012). Seleksi pada sapi potong dibedakan menjadi dua metode pokok yaitu seleksi secara tradisional (kualitatif) dan seleksi secara kuantitatif yaitu metode yang didasarkan pada perhitungan kuantitatif (Hardjosubroto, 1994; Amalia, 2015). Kriteria seleksi adalah bobot lahir yang mempunyaikorelasi positif dengan potensi pertumbuhan sapi pada masa berikutnya (Adinata, 2013).

Bobot lahir merupakan bobot pada saat pertama kali ternak dilahirkan. Bobot lahir pedet adalah salah satu yang mempengaruhi performan pedet dan menjadi informasi pertama terhadap potensi pengembangan sapi (Adinata, 2013). Bobot lahir pedet merupakan salah satu nilai pemuliaan yang dapat digunakan untuk seleksi produksi dan efisiensi reproduksi (Olawuni dan Salako, 2010). Bobot lahir dapat digunakan untuk melakukan seleksi betina yang dapa digunakan sebagai bibit.

Bobot sapih merupakan bobot pedet saat mulai dipisahkan dari induknya. Bobot sapih dapat digunakan sebagai salah satu faktor untuk melakukan seleksi betina karena bobot sapih akan menunjukkan keadaan selanjutnya yang dipengaruhi oleh lingkungan. Faktor yang mempengaruhi bobot sapih diantaranya adalah faktor lingkungan yaitu manajemen pemeliharaan dan manajemen produksi susu induk (Prihandini et al., 2011).

Nilai pemuliaan dari seekor ternak adalah sebuah gambaran nilai gen-gen yang bersangkutan untuk diturunkan pada keturunannya (Handiwirawan, 2011). Kekuatan pewarisan dan mutu genetik ternak dari sifat-sifat yang diperbaiki akan menentukan kemajuan mutu genetik (Putra et al., 2014a). Nilai pemuliaan ini perlu diketahui untuk dapat melakukan seleksi sehingga dapat diperoleh betina unggul yang dapat dijadikan bibit.

Seleksi betina dapat menjadi sangat penting dilakukan agar dapat diperoleh bibit yang memiliki kualitas genetik baik. Bibit unggul hasil seleksi ini dapat terus dipelihara untuk terus menghasilkan keturunan yang memiliki kualitas baik, sehingga dapat membantu meningkatkan populasi ternak yang ada di Indonesia. Betina yang tidak masuk dalam seleksi dapat di keluarkan untuk diganti dengan betina yang unggul lainnya sehingga pemeliharaan menjadi lebih efisien.

Seleksi dapat dilakukan dengan cara melakukan pendugaan nilai pemuliaan. Pendugaan nilai pemuliaan dapat dilakukan dengan dua metode yaitu metode jangka pendek Most Probable Producing Ability (MPPA) dan metode jangka panjangEstimated Breeding Value (EBV) (Kurnianto, 2012). MPPA merupakan pendugaan secara maksimum dan kemampuan berproduksi seekor ternak betina yang dihitung atas dua perfrma yang sudah ada. EBV merupakan faktor utama dalam melakukan evaluasi keunggulan sifa produksi dan reproduksi individu dalam populasi untuk seleksi ternak (Prihanisa et al., 2011).

Tujuan dari penelitian ini adalah untuk mengetahui keunggulan genetik dari ternak betina yang ada di Satker-Sumberejo Kendal melalui dua metode yang berbeda. Manfaat penelitian ini adalah untuk mengetahui betina unggul dengan pendugaan dari bobot lahir dan bobot sapih pedet untuk nantinya dapat dilakukan seleksi betina unggul yang dapat dijadikan bibit. 


\section{MATERI DAN METODE}

Penelitiandilaksanakanpada bulan Juli - Oktober 2016 di Satker Sumberejo, Kendal. Sakter Sumberejo ini merupakan satuan kerja dibawah naungan Balai Pembibitan dan Budidaya Ternak Ruminansia (BPPTR).

\section{Materi}

Materi yang digunakan dalam penelitian ini adalah berupa cacatan (recording) yang berisi mengenai identitas induk, umur induk, identitas pedet, catatan tanggal lahir pedet, bobot lahir (BL), panjang badan (PB), tinggi pundak (TP) dan lingkar dada (LD) di Satker Sumberejo Kendal.

\section{Metode}

Metode yang dilakukan dalam penelitian ini adalah observasi. Catatan yang diambil adalah data induk dan data anak. Catatan data anak yang diambil adalah bobot lahir (BL) sera bobot sapih (BS) dan data penunjang mengenai ukuran tubuh yaitu tinggi pundak (TP), panjang badan (PB) dan lingkar dada (LD). Data bobot lahir diperoleh dengan cara melakukan penimbangan terhadap ternak dengan menggunakan timbangan ternak.

Data tinggi pundak $(\mathrm{cm})$ diperoleh dengan cara mengukurtinggi pundak melewati bagian belakang scapula tegak lurus dengan tanah menggunakan tongkat ukur (Niam et al., 2012). Data panjang badan $(\mathrm{cm})$ diperoleh dengan cara melakukan pengukuran dari tepi tulang humerus sampai tulang duduk dengan menggunakan tongkat ukur (Syawal et al., 2013). Data lingkar dada (cm) diperoleh dengan cara melingkarkan pita ukur $(\mathrm{cm})$ di sekeliling rongga dada, dibelakang sendi bahu (os scapula) (Hadziq, 2011).

Analisis dilakukan terhadap bobot badan dan bobot sapih menggunakan ratarata (mean), standar deviasi dan koefisien keragaman dengan rumus-rumus sebagai berikut: a) Rataan Sifat $(\overline{\boldsymbol{X}})$; (Kurnianto, 2012).

$$
\overline{\mathrm{X}} \quad=\frac{\sum \mathrm{Xi}}{\mathrm{n}}
$$

Keterangan $: \bar{X}=$ Rataan nilai yang diamati, $\mathrm{X}_{\mathrm{i}}=$ Nilai ke-i yang diamati, $\mathrm{n}=$ jumlah data

b) Simpangan Baku (Sb); (Mas dan Prastiwi, 2016).

$$
\mathrm{Sb}=\sqrt{\frac{\sum \mathrm{X}^{2}-\frac{\left(\sum \mathrm{X}\right)^{2}}{\mathrm{n}}}{\mathrm{n}-1}}
$$

c) Koefisien Keragaman

(Kurnianto, 2012).

(KK);

$$
\mathrm{KK}=\frac{\mathrm{Sb}}{\overline{\mathrm{X}}} \times 100 \%
$$

Kategori keragaman $:<5 \%=$ Keragaman kecil , 6\% - 14\% = Keragaman sedang, $>15 \%=$ Keragaman besar

\section{d) Perhitungan Bobot Lahir dan Bobot Sapih Terkoreksi}

Perhitungan ini bobot lahir dan bobot sapih terkoreksi ini dengan faktor koreksi umur induk dan faktor koreksi jenis kelamin dilakukan dengan tujuan untuk menghilangkan bias bobot pedet karena pengaruh umur induk dan jenis kelamin.

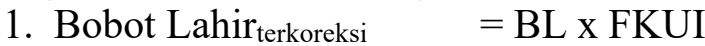
$\mathrm{x} \mathrm{FKJK}_{\mathrm{BL}}$
Keterangan :
Bobot Lahir terkoreksi $=$ Bobot lahir terkoreksi dengan umur induk dan jenis kelamin
FKUI $=$ Faktor koreksi umur induk
FKJK $_{\mathrm{BL}} \quad=$ Faktor koreksi jenis kelamin pada bobot lahir.
FKJK $_{\mathrm{BL}}=\frac{\text { Rataan BL jantan }}{\text { Rataan BL betina }}$

2. $\mathrm{BS}_{205}=\left[\frac{\mathrm{BS}-\mathrm{BL}}{\mathrm{umur}} \mathrm{x}\right] \quad 205+$

$\mathrm{BL}(\mathrm{FKUI})\left(\mathrm{FKJK}_{\mathrm{BS}}\right) \ldots \ldots \ldots \ldots \ldots(2)$ 
Keterangan :

$\mathrm{BS}_{205}=$ bobot sapih terkoreksi pada umur 205 hari

BS = bobot sapih

BL = bobot lahir

FKUI $=$ faktor koreksi umur induk

$\mathrm{FKJK}_{\mathrm{BS}}=$ faktor koreksi jenis kelamin bobot sapih

$\mathrm{FKJK}_{\mathrm{BS}}=\frac{\text { Rataan BS jantan }}{\begin{array}{l}\text { Rataan BS betina } \\ \text { 2014b). }\end{array}}$ Putra et al.,

Faktor koreksi yang digunakan untuk umur induk yaitu umur 2 tahun $(1,15) ; 2,5$ tahun $(1,07) ; 3$ tahun $(1,10) ; 4$ tahun $(1,05) ; 5-9$ tahun $(1,00)$; 10-11 tahun $(1,03)$ dan $>11$ tahun $(1,05)$ (Hardjosubroto, 1994). Faktor koreksi jenis kelamin dilakukanuntuk mengurangi bias denganmelakukan penyetaraan jenis kelamin betina ke jenis kelamin jantan (Putra et al., 2014b).

\section{e) Pendugaan nilai pemuliaan}

Melakukan pendugaan nilai pemuliaan dengan menggunakan metode MPPA (Most Probable Producing Ability) dengan berdasarkan pada penampilan turunannya. Rumusnya adalah:

1) $\mathrm{MPPA}=\overline{\mathrm{P}}_{\mathrm{P}}+\frac{\mathrm{nr}}{1+(\mathrm{n}-1) \mathrm{r}}[\overline{\mathrm{P}} \mathrm{i}-$ $\left.\overline{\mathrm{P}}_{\mathrm{P}}\right]$

Keterangan:

$$
\begin{aligned}
& \overline{\mathrm{P}}_{\mathrm{P}}=\text { rataan bobot badan populasi } \\
& \mathrm{n}=\text { jumlah beranak } \\
& \mathrm{r}
\end{aligned}
$$

$\overline{\mathrm{P}}_{\mathrm{i}} \quad=$ rataan bobot badan anak dari induk yang dihitung nilai MPPAnya(Kurnianto, 2012).

2) $\left.\mathrm{EBV} \quad=\frac{\mathrm{nh}^{2}}{1+(\mathrm{n}-1) \mathrm{r}}\left[\overline{\mathrm{P}} \mathrm{i}-\overline{\mathrm{P}}_{\mathrm{P}}\right] \ldots . .4\right)$

Keterangan:

$\mathrm{h}^{2}=$ heritabilitas bobot badananak

Nilai iritabilitas yang digunakan untuk sapi potong bobot lahir adalah 0,20 sedangkan untuk nilai iritabilitas sapi potong untuk bobot sapih adalah 0,4 . Nilai heritabilitas yang digunakan untuk bobot lahir adalah 0,34 dan untuk bobot sapih adalah 0,33 (Kurnianto, 2009).

\section{f) Korelasi peringkat Spearman}

Korelasi

peringkat

Spearmandigunakan untuk menguji signifikasi peringkat keunggulan betina berdasarkan bobot lahir (BL) dan bobot sapih (BS) anak. Rumusnya adalah:

$\rho \quad=1-\frac{6 \sum b_{i}^{2}}{n\left(n^{2}-1\right)}$.

Keterangan :

$\rho=$ koefisien korelasi peringkat spearman

$\mathrm{n}$ = banyaknya pasang peringkat

$\mathrm{b}_{\mathrm{i}}=$ selisih setiap pasang peringkat yang berkaitan dengan pasang data penting keunggulan betina(Usman, 1995).

\section{HASIL DAN PEMBAHASAN \\ Bobot Badan Pedet}

Rataan, simpangan baku dan koefisien keragaman pada bobot lahir dan bobot sapih sapi Peranakan Ongole (PO) tersaji dalam Tabel 1.

Tabel 1. Rataan, Simpangan Baku dan Koefisien Keragaman Bobot Lahir dan Bobot Sapih Sapi PO

\begin{tabular}{lccc}
\hline \hline \multicolumn{1}{c}{ Bobot Badan $(\mathrm{kg})$} & JumlahData & $\overline{\mathrm{X}} \pm \mathrm{Sb}$ & KK (\%) \\
\hline Saat Lahir & 59 & $29,35 \pm 2,13$ & 7,26 \\
Saat Sapih & 59 & $112,58 \pm 24,17$ & 21,47 \\
\hline
\end{tabular}

Keterangan:

$\mathrm{Sb}$ : Simpangan baku,

KK : Koefisien Keragaman.

Tabel 1 menerangkan bahwa rataan bobot lahir pedet sapi PO yang ada di Satker Kendal adalah 29,35 $\pm 2,13$ sedangkan untuk rataan bobot sapih adalah 112,58 $\pm 21,47$. Hasil rataan ini lebih tinggi dari penelitian Adinata (2013) yang menyebutkan bahwa 
rata-rata bobot lahir sapi PO adalah $25,93 \pm 3,97$. Keragaman bobot lahir termasuk dalam kategori sedang sedangkan untuk bobot sapih termasuk dalam kategori tinggi.Baco et al. (2011) menyatakan bahwa keragaman dapat digunakan untuk titik awal melakukan peningkatan kualitas dan kuantitas suatu populasi, nilai keragaman yang tinggi dapat dipengaruhi oleh faktor genetik atau masih terjadi inbreeding dan faktor lingkungan.Faktorfaktor yang mempengaruhi bobot lahir adalah jenis kelamin, umur induk, jenis kelamin dan jumlah kelahiran. Menurut
Hartati dan Dikman (2007), faktor-faktor mempengaruhi bobot lahir pedet yang ditimbang dalam kurun waktu 24 jam setelah dilahirkan adalah umur induk, jenis kelamin, bangsa pejantan, jumlah kelahiran dan masa kelahiran. Muslim et al. (2013) menyatakan bahwa kisaran bobot lahir pedet adalah $20-35 \mathrm{~kg}$.

\section{Bobot Badan Pedet Terstandarisasi}

Rataan, simpangan baku dan koefisien keragaman pada bobot lahir dan bobot sapih sapi PO terstandarisasi tersaji dalam Tabel 2.

Tabel 2. Rataan, Simpangan Baku dan Koefisien Keragaman Bobot Lahir dan Bobot Sapih Tersandarisasi Sapi PO

\begin{tabular}{lccc}
\hline \hline Bobot Badan $(\mathrm{kg})$ & JumlahData & $\overline{\mathrm{X}} \pm \mathrm{Sb}$ & KK (\%) \\
\hline Saat Lahir & 59 & $30,91 \pm 1,97$ & 6,37 \\
Saat Sapih & 59 & $110,10 \pm 11,20$ & 10,17 \\
\hline
\end{tabular}

Keterangan:

$\mathrm{Sb} \quad$ : Simpangan baku,

KK : Koefisien Keragaman.

Bobot lahir dan bobot sapih perlu dilakukan standarisasi, bobot lahir dan bobot sapih pedet betina dikoreksi terhadap pedet jantan, sedangkan untuk pedet jantan tidak perlu dilakukan koreksi/standarisasi.Perbedaan umur induk juga merupakan salah satu faktor yang digunakan untuk koreksi. Rataan bobot lahir terstandarsasi adalah 30,91 $\pm 1,97$, sedangkan untuk rataan bobot sapih terstandarisasi adalah 110,10 $\pm 11,20$. Menurut Putra et al. (2014b) perhitungan bobot lahir dan bobot sapih terstandarisasi ini dengan faktor koreksi umur induk dan faktor koreksi jenis kelamin dilakukan untuk menghilangkan bias bobot pedet karena pengaruh umur induk dan jenis kelamin pedet. Berdasarkan hasil perhitungan diketahui bahwa rataan bobot lahir dan bobot sapih memiliki keragaman sedang. Hal ini menunjukkan bahwa dengan adanya perhitungan standarisasi mengakibatkan adanya penurunan nilai koefisien keragaman, yang dapat dimaknai bahwa data tersebut semakin seragam.
Rahayu et al. (2013) menyatakan bahwa koreksi atau standarisasi data menyebabkan data semakin seragam dan mengurangi tingkat keragaman data. Menurut Lasley (1978), koreksi terhadap faktor lingkungan yang mempengaruhi produksi ternak akan membuat seleksi menjadi lebih efektif sehingga ternak yang baik akan tampak unggul hanya berdasarkan faktor genetiknya. Bobot sapih banyak dipengaruhi oleh lingkungan yaitu manajemen pemeliharaannya. Menurut Prihandini et al. (2011), bobot sapih banyak dipengaruhi faktor lingkungan diantaranya manajemen pemeliharaan dan produksi susu induk. Umur sapih juga berpengaruh terhadap bobot sapih pedet.Standarisasi bobot sapih pedet biasanya dilakukan pada umur 205 hari.Hardjosubroto (2014) menyatakan bahwa koreksi bobot sapih dilakukan pada hari ke-205 hari.

\section{Pendugaan Nilai Pemuliaan}

Hasil pendugaan nilai pemuliaan menggunakan metode MPPA dan EBV pada bobot lahir disajikan pada Tabel 3 . 
Tabel 3. Hasil Perhitungan MPPA dan EBV pada Bobot Lahir Sapi PO

\begin{tabular}{|c|c|c|c|c|c|}
\hline \multirow[t]{2}{*}{ No } & \multirow[t]{2}{*}{ No Eartag } & \multicolumn{4}{|c|}{ Bobot Lahir } \\
\hline & & MPPA & Peringkat & EBV & Peringkat \\
\hline 1 & 4012 & 31,1371 & 14,5 & 0,1187 & 4 \\
\hline 2 & 4006 & 31,3138 & 9 & 0,2219 & 3 \\
\hline 3 & 4005 & 30,7608 & 28 & $-0,1010$ & 44 \\
\hline 4 & 4018 & 30,6050 & 40 & $-0,1920$ & 46 \\
\hline 5 & 4027 & 31,3673 & 5,5 & 0,0512 & 7,5 \\
\hline 6 & $0707 / 059$ & 30,4000 & 44 & $-0,3117$ & 47 \\
\hline 7 & $0715 / 043$ & 31,7360 & 2 & 0,4684 & 1 \\
\hline 8 & $112 / 0711$ & 29,9364 & 48 & $-0,5824$ & 48 \\
\hline 9 & 730/0701 & 30,9125 & 27 & $-0,0142$ & 28 \\
\hline 10 & 0722 & 31,5815 & 3 & 0,0760 & 6 \\
\hline 11 & 0731 & 30,7602 & 29 & $-0,1013$ & 45 \\
\hline 12 & 4014 & 30,6994 & 38 & 0,0235 & 19,5 \\
\hline 13 & $052 / 0716$ & 31,4061 & 4 & 0,3439 & 2 \\
\hline 14 & 099/0737 & 30,7247 & 35 & $-0,0230$ & 34 \\
\hline 15 & 065/0718 & 30,5105 & 42,5 & $-0,0478$ & 39,5 \\
\hline 16 & 076/4013 & 30,9389 & 21,5 & 0,0017 & 22,5 \\
\hline 17 & 118/0709 & 31,1531 & 14,5 & 0,0265 & 15 \\
\hline 18 & $0572 / 4041$ & 30,7247 & 35 & $-0,0230$ & 34 \\
\hline 19 & $019 / 4040$ & 30,7271 & 31 & $-0,0228$ & 30 \\
\hline 20 & $447 / 4019$ & 30,7271 & 31 & $-0,0228$ & 30 \\
\hline 21 & $097 / 0734$ & 30,7247 & 35 & $-0,0230$ & 34 \\
\hline 22 & $0440 / 6623$ & 31,3245 & 8 & 0,0463 & 10 \\
\hline 23 & $053 / 0717$ & 30,5271 & 41 & $-0,0459$ & 38 \\
\hline 24 & $105 / 0723$ & 31,3271 & 7 & 0,0466 & 9 \\
\hline 25 & 0408/9714 & 31,2495 & 10 & 0,0376 & 11 \\
\hline 26 & $0441 / 6611$ & 30,9389 & 21,5 & 0,0017 & 22,5 \\
\hline 27 & $087 / 0742$ & 30,9271 & 24,5 & 0,0004 & 25,5 \\
\hline 28 & $136 / 0759$ & 31,1531 & 14,5 & 0,0265 & 15 \\
\hline 29 & $103 / 0726$ & 31,1531 & 14,5 & 0,0265 & 15 \\
\hline 30 & $033 / 4158$ & 31,1531 & 14,5 & 0,0265 & 15 \\
\hline 31 & $4159 / 4039$ & 30,9271 & 24,5 & 0,0004 & 25,5 \\
\hline 32 & $057 / 4036$ & 30,9271 & 24,5 & 0,0004 & 25,5 \\
\hline 33 & $040 / 4142$ & 30,0821 & 46,5 & $-0,0973$ & 42,5 \\
\hline 34 & $0410 / 6614$ & 30,6071 & 39 & $-0,0366$ & 37 \\
\hline 35 & $014 / 4023$ & 30,0821 & 46,5 & $-0,0973$ & 42,5 \\
\hline 36 & 088/0727 & 30,7247 & 35 & $-0,0230$ & 34 \\
\hline 37 & $107 / 0746$ & 31,1531 & 14,5 & 0,0265 & 15 \\
\hline 38 & $4154 / 0529$ & 31,1271 & 19 & 0,0235 & 19,5 \\
\hline 39 & $146 / 331$ & 30,3498 & 45 & $-0,0664$ & 41 \\
\hline 40 & $0883 / 0415$ & 31,3673 & 5,5 & 0,0512 & 7,5 \\
\hline 41 & $4032 / 4152$ & 31,1531 & 14,5 & 0,0265 & 15 \\
\hline 42 & $100 / 0745$ & 30,7247 & 35 & $-0,0230$ & 34 \\
\hline 43 & $4147 / 4007$ & 30,9271 & 24,5 & 0,0004 & 25,5 \\
\hline 44 & 0333/0874 & 31,0271 & 20 & 0,0119 & 21 \\
\hline 45 & $006 / 4010$ & 31,7957 & 1 & 0,1008 & 5 \\
\hline 46 & $029 / 4157$ & 30,7271 & 31 & $-0,0228$ & 30 \\
\hline 47 & $0438 / 6627$ & 30,5105 & 42,5 & $-0,0478$ & 39,5 \\
\hline 48 & $077 / 4004$ & 31,1531 & 14,5 & 0,0265 & 15 \\
\hline
\end{tabular}


Tabel 3 menyajikan hasil perhitungan MPPA dan EBV pada bobot lahir. Diketahui pada MPPA hasil perhitungan tertinggi yaitu nomor eartag006/4010 $(31,80 \mathrm{~kg})$, sedangkan untuk nilai yang terendah adalah eartag 112/0711 $(29,94 \mathrm{~kg})$. Nilai EBV tertinggi diketahui adalah nomor eartag 0715/043 (0,48 kg), sedangkan untuk nilai terendah adalah nomor eartag $014 / 4023(-0,02 \mathrm{~kg})$. Nilai pemuliaan yang tinggi dapat digunakan sebagai bibit unggul untuk diwariskan pada keturunannya. Menurut Amalia (2015), nilai EBV ataupun MPPA yang tinggi menunjukkan bahwa ternak tersebut unggul maka kelebihannya dapat diwariskan pada keturunannya, sedangkan untuk NP negatif tidak layak untuk dijadikan bibit sehingga jika diwariskan pada keturunannya tidak akan menampilkan sifat unggul. Menurut Handiwirawan (2011), merangking ternak dengan menggunakan EBV cenderung lebih mendekati ke true breeding value. Dibandingkan dengan MPPA perhitungan dengan EBV lebih akurat perkiraan true breeding value yang telah dibuat tersebut.

Pendugaan nilai pemuliaan menggunakan metode MPPA dan EBV pada bobot sapih tersaji pada Tabel 4.

Tabel 4. Hasil Perhitungan MPPA dan EBV pada Bobot Sapih PO

\begin{tabular}{|c|c|c|c|c|c|}
\hline \multirow[t]{2}{*}{ No } & \multirow{2}{*}{ No Eartag } & \multicolumn{4}{|c|}{ Bobot Lahir } \\
\hline & & MPPA & Peringkat & EBV & Peringkat \\
\hline 1 & 4012 & 115,4622 & 1 & 3,1330 & 1 \\
\hline 2 & 4006 & 112,6686 & 10 & 1,5017 & 3 \\
\hline 3 & 4005 & 102,4439 & 48 & $-4,4689$ & 48 \\
\hline 4 & 4018 & 110,3862 & 25 & 0,1689 & 15 \\
\hline 5 & 4027 & 109,377 & 29 & $-0,0832$ & 28 \\
\hline 6 & $0707 / 059$ & 106,3688 & 47 & $-2,1770$ & 47 \\
\hline 7 & $0715 / 043$ & 109,5595 & 27 & $-0,3138$ & 42 \\
\hline 8 & $112 / 0711$ & 111,0819 & 14 & 0,5751 & 4 \\
\hline 9 & 730/0701 & 108,575 & 35 & $-1,8850$ & 46 \\
\hline 10 & 0722 & 110,6118 & 21 & 0,0595 & 23 \\
\hline 11 & 0731 & 110,481 & 23 & 0,2243 & 13 \\
\hline 12 & 4014 & 111,7205 & 12 & 0,1877 & 14 \\
\hline 13 & $052 / 0716$ & 112,9651 & 7 & 1,6748 & 2 \\
\hline 14 & 099/0737 & 110,808 & 16,5 & 0,0822 & 18,5 \\
\hline 15 & 065/0718 & 110,4697 & 24 & 0,0431 & 25 \\
\hline 16 & $076 / 4013$ & 109,3795 & 28 & $-0,0829$ & 27 \\
\hline 17 & $118 / 0709$ & 108,5671 & 36 & $-0,1768$ & 41 \\
\hline 18 & $0572 / 4041$ & 110,808 & 16,5 & 0,0822 & 18,5 \\
\hline 19 & $019 / 4040$ & 114,2415 & 3 & 0,4791 & 6 \\
\hline 20 & $447 / 4019$ & 113,1213 & 5 & 0,3496 & 8 \\
\hline 21 & 097/0734 & 110,0291 & 26 & $-0,0078$ & 26 \\
\hline 22 & $0440 / 6623$ & 112,9142 & 9 & 0,3257 & 11 \\
\hline 23 & $053 / 0717$ & 113,8174 & 4 & 0,4301 & 7 \\
\hline 24 & $105 / 0723$ & 107,0653 & 45 & $-0,3505$ & 44 \\
\hline 25 & $0408 / 9714$ & 108,4032 & 39 & $-0,1958$ & 37 \\
\hline 26 & $0441 / 6611$ & 107,2565 & 44 & $-0,3284$ & 43 \\
\hline 27 & 087/0742 & 108,2635 & 40 & $-0,2119$ & 38 \\
\hline 28 & $136 / 0759$ & 106,9068 & 46 & $-0,3688$ & 45 \\
\hline 29 & $103 / 0726$ & 109,357 & 30 & $-0,0855$ & 29 \\
\hline 30 & $033 / 4158$ & 108,7298 & 33 & $-0,1580$ & 32 \\
\hline 31 & $4159 / 4039$ & 110,6327 & 20 & 0,0620 & 22 \\
\hline 32 & $057 / 4036$ & 113,0732 & 6 & 0,3440 & 9 \\
\hline 33 & $040 / 4142$ & 109,2183 & 31 & $-0,1016$ & 30 \\
\hline 34 & $0410 / 6614$ & 110,7049 & 18 & 0,0703 & 20 \\
\hline
\end{tabular}




\begin{tabular}{cccccc}
35 & $014 / 4023$ & 108,6329 & 34 & $-0,1692$ & 33 \\
36 & $088 / 0727$ & 108,1475 & 41 & $-0,2254$ & 39 \\
37 & $107 / 0746$ & 107,8935 & 43 & $-0,2547$ & 34 \\
38 & $4154 / 0529$ & 111,0568 & 15 & 0,1110 & 17 \\
39 & $146 / 331$ & 108,842 & 32 & $-0,1451$ & 31 \\
40 & $0883 / 0415$ & 108,0802 & 42 & $-0,2331$ & 40 \\
\hline 41 & $4032 / 4152$ & 108,5207 & 38 & $-0,1822$ & 36 \\
42 & $100 / 0745$ & 108,5656 & 37 & $-0,1770$ & 35 \\
43 & $4147 / 4007$ & 112,4251 & 11 & 0,2691 & 12 \\
44 & $0333 / 0874$ & 112,962 & 8 & 0,3312 & 10 \\
45 & $006 / 4010$ & 110,4909 & 22 & 0,0455 & 25 \\
46 & $029 / 4157$ & 114,4436 & 2 & 0,5025 & 5 \\
47 & $0438 / 6627$ & 111,3716 & 13 & 0,1474 & 16 \\
48 & $077 / 4004$ & 110,6811 & 19 & 0,0675 & 21 \\
\hline
\end{tabular}

Tabel 4 menunjukkan bahwa hasil perhitungan MPPA dan EBV pada bobot sapih diketahui pada peringkat pertama yaitu eartag 4012 secarat berurutan sebesar $115,46 \mathrm{~kg}$ dan $3,13 \mathrm{~kg}$. Hal ini menunjukkan bahwa stabilitas peringkat tersebut dapat dijadikan rekomendasi bahwa sapi dengan eartag 4012 layak dijadikan sebagai bibit. Suhada et al. (2009) menyatakan bahwa semakin tinggi nilai pemuliaan seekor ternak, maka kelebihannya akan diwariskan pada keturunannya. Menurut Komala (2015), ternak yang memiliki daya produksi yang tinggi akan memiliki peringkat MPPA yang tinggi pula dibandingkan dengan rataan populasi. Nilai pemuliaan terendah pada dua metode MPPA dan EBV adalah sapi dengan eartag 4005 dengan nilai berurutan $102,44 \mathrm{~kg}$ dan $-4,47 \mathrm{~kg}$. Hal ini dapat dijadikan rekomendasi pada pihak peternak untuk melakukan tindakan pengeluaran ternak dan dapat digantikan dengan ternak yang lainnya.Menurut Suhada et al. (2009) nilai MPPA yang tinggi akan memiliki nilai keunggulan yang lebih baik jika dbanding MPPA yang rendah oleh sebab itu hasil ini dapat dijadikan acuan untuk melakukan culling pada induk yang memiliki nilai MPPA yang rendah.

\section{Korelasi Peringkat Spearman}

Korelai peringkat Spearman digunakan untuk membandingkan dua peringkat yang berbeda. Menurut Usman (1995) korelasi rank Spearman dipakai apabila kedua varabel yang dikorelasikan mempunyai tingkatan data ordinal. Hasil perhitungan dengan analisis Spearman pada bobot lahir dengan menggunakan dua metode yaitu MPPA dan EBV adalah 0,94dan nilai t-hitung adalah 15,94. Sedangkan untuk hasil analisis Spearman pada bobot sapih adalah 0,95 dan untuk thitung adalah 20,38. Nilai t-tabel yang diperoleh dari tabel B menurut Zar (1984) adalah 0,288, maka dapat disimpulkan bahwa evaluasi keunggulan genetik dengan menggunakan dua metode memiliki hubungan.Menurut Handiwirawan (2011) merangking ternak dengan menggunakan EBV cenderung lebih mendekati ke True breeding value, lebih akurat perkiraan true breeding value yang telah dibuat tersebut.Nilai keakuratan EBV lebih diakui daripada nilai keakuratan MPPA. Menurut Subandriyo et al. (1999) bahwa perhitungan MPPA apabila catatan silsilahnya sedikit maka hasilnya relatif sama dengan keadaan saat ini.

\section{SIMPULAN}

Berdasarkan hasil analisis Spearman dapat disimpulkan bahwa evaluasi genetik dengan dua metode yaitu MPPA dan EBV memiliki hubungan sehingga keduanya dapat dijadikan pedoman dalam melaksanakan seleksi. 


\section{DAFTAR PUSTAKA}

Adinata, Y. 2013. Estimasi Nilai Pemuliaan Bobot Lahir Sapi Peranakan Ongole pada Unit Pengelolaan Bibit Sumber di Loka Penelitian Sapi Potong. Prosiding Seminar Nasional Teknologi Peternakan dan Veteriner. Medan, 3-5 Sepetember. Hal 66-73.

Amalia, E. V. 2015. Ukuran-ukuran Tubuh dan Estimasi Nilai Pemuliaan Pejantan Sapi Potong di Satker Sumberejo Kendal. Fakultas Peternakan Universitas Diponegoro. (Skripsi).

Baco, S., R. Malaka dan L. Rahim. 2011. Kesamaan genetik antar populasi sapi Bali dan hasil silangannya dengan sapi Simmental. Jurusan Produksi Ternak. Fakultas Peternakan. Universitas Hasanuddin, Makasar.

Hadziq, A. 2011. Status Fisiologis dan Performa Pedet Peranakan Friesian Holstein Prasapih yang diinokulasi Bakteri Pencerna Serat dengan Pakan Bersuplemen Kobalt. Fakultas Peternakan Institut Pertanian Bogor. (Skripsi).

Handiwirawan, E. 2011. Seleksi pada Ternak Kerbau Berdasarkan Nilai Pemuliaan. Lokakarya Nasional Usaha Ternak Kerbau Mendukung Program Kecukupan daging Sapi. Hal:79-88.

Handiwirawan, E dan Subandriyo. 2004. Potensi dan keragaman sumberdaya genetik sapi Bali. Wartazoa. 14(3):50-60.

Hardjosubroto, W.1994. Aplikasi Pemuliabiakan Ternak di Lapangan. Gramedia Widiasarana, Jakarta.
Hartati dan D. M. Dikman. 2007. Performans pedet sapi Peranakan Ongole (PO) pada kondisi pakan low external input. Prosiding Seminar Nasional Teknologi Peternakan dan Veteriner. 21-22:137-142.

Komala, I., I. Arifiantini., C. Sumantri dan L. I. T. A. Tumbelaka. 2015. Hubungan produksisusu berdasarkan grade MPPA dengan performa reproduksi. J. Ilmu Produksi dan Teknologi Hasil Peternakan. 03(1):33-39.

Kurnianto, E. 2009. Pemuliaan Ternak. Graha Ilmu, Yogyakarta.

Kurnianto, E. 2012. Buku Ajar Ilmu Pemuliaan Ternak. Penerbit Universitas Diponegoro, Semarang.

Lasley. 1978. Genetics of Livestock Improvement Third Edition PrenticeHall of India Private Limited, New Delhi.

Mas, I. K. G. Y. dan W. D. Prastiwi. 2016. Biometrika Peternakan. Media Inspirasi Semesta, Semarang.

Muslim, K. N., H. Nugroho dan T. Susilowati. 2013. Hubungan antara bobot induk dan bobot lahir pedet sapi Brahman cross pada jenis kelamin berbeda. J. Ilmu-ilmu Peternakan. 23(1):18-24.

Niam, H.U.M., A. Purnomoadi dan S. Dartokarno. 2012 Hubungan antara ukuran-ukuran tubuh dengan bobot badan sapi bali betina pada berbagai kelompok umur. J. Animal Agriculture. 1 (1): 541-556.

Olawuni, S. O dan A. E. Salako. 2010. Genetic parameters and factors affecting reproductiveperformance of White Fulani Cattle in Southwestern, Nigeria. Global Veterinaria. 5(5): 255-258. 
Prihanisa, H., Sumadi dan Ardianto. 2011. Estimasi potensi genetik sapi Perah Frisian Holstein di Taurus Dairy Farm, Cicurug, Sukabumi. Bul. Pet. 35(2): 517-525.

Prihandini, P. W. 2005. Pengaruh manajemen pemeliharaan kelompok dan individu sapi potong Peranakan Ongole terhadap pertambahan berat badn harian. Widyariset.8(2):517525 .

Putra, W. P. B., Sumadi dan T. Hartatik. 2014. Pendugaan bobot badan pada sapi Aceh dewasa menggunakan ukuran tubuh. J. Ilmu Ternak. 3(2): 17.

Putra, W.P. B., Sumadi., H. Tety dan S. Hendra. 2014. Potensi respon seleksi sifat pertumbuhan sapi Aceh. JIVT. 19(4): 248-256.

Rahayu, A., S. A. Santosa dan A. Susanto. 2013. Evaluasi mutu genetik sapi Perah menggunakan catatan produksi susu harian dan Centering Date Method (CDM). 1(1):236-243.

Subandriyo., B. Setiadi., E. Handiwirawan dan E. Suparyanto.1999. Performa Domba Komposit Hasil Persilangan Antara Domba Lokal Sumatera dengan Domba Rambut pada Kondisi di Kandangkan. Seminar Nasional Peternakan dan Veteriner Ciawi Bogor. Tanggal 03-04 Oktober 1999. Hal:365-368.

Suhada, H., Sumadi dan N. Ngadiyono. 2009. Estimasi parameter genetik sifat produksi sapi Simmental di Balai Pembibitan Ternak Unggul Sapi Potong Padang Mangatas, Sumatera Barat. Buletin Peternakan. 3(3): 1-7.
Syawal, S., B. P. Purwanto dan I. G. Permana. 2013. Studi hubungan respon ukuran tubuh dan pemberian pakan terhadap pertumbuhan sapi pedet dan dara pada lokasi yang berbeda. JITP. 2 (3): 175-188.

Usman, H. $1995 . \quad$ Pengantar Statistika.BumiAksara, Jakarta. 